\title{
Entrepreneurship, Organization Capital and the Evolution of the Firm
}

\author{
ATSUSHI OSHIMA \\ B. RAVIKUMAR \\ RAYMOND RIEZMAN
}

CESIFO Working PAPER No. 2242

CATEGORY 9: INDUSTRIAL ORGANISATION

MARCH 2008

\footnotetext{
An electronic version of the paper may be downloaded

- from the SSRN website: Www.SSRN.com

- from the RePEc website: Www.RePEc.org

- from the CESifo website: www.CESifo-group.org/wp
} 


\title{
Entrepreneurship, Organization Capital and the Evolution of the Firm
}

\author{
Abstract \\ We view the entrepreneur as an agent who possesses human capital in the form of specific \\ skills or talents. When she starts a firm, her human capital is essential to the firm and it has \\ substantial private value. The entrepreneur transforms her human capital over time into what \\ we call 'organization capital'. This organization capital can be sold as part of the firm, so the \\ dynamic process of transforming specific human capital into organization capital means that \\ the value of the firm increases over time. \\ JEL Code: L26, D92. \\ Keywords: organization capital, entrepreneur. \\ Atsushi Oshima \\ Department of Economics \\ University of Iowa \\ Iowa City, IA 52242 \\ USA \\ atsushi-oshima@uiowa.edu \\ B. Ravikumar \\ Department of Economics \\ University of Iowa \\ Iowa City, IA 52242 \\ USA \\ ravikumar@uiowa.edu \\ Raymond Riezman \\ Department of Economics \\ University of Iowa \\ Iowa City, IA 52242 \\ USA \\ raymond-riezman@uiowa.edu
}

We would like to dedicate this paper to the memory of Koji Shimomura. 


\section{Introduction}

The study of how and why firms get started has a rich tradition in the economics literature. Knight (1971) views an entrepreneur as someone who accepts production risk in exchange for the authority to direct other factors of production; this view is essentially static and helps identify entrepreneurial activity with the risk characteristics of the population. Kihlstrom and Laffont (1979) view an entrepreneur as someone who bears risk and receives the reward for the risk. Schumpeter (1949) thinks of the entrepreneur as someone who transforms inventions and discoveries into commercially viable processes. Baumol $(1986,1988)$ and Holmes and Schmitz (1990) focus on the entrepreneur's role in adapting new technology to create new products.

Our theory of the entrepreneur differs from previous theories in one important aspect: we view the entrepreneur as an organizer of production who transforms a specific, non-tradable capital into a general, tradable capital. The entrepreneur is an agent who possesses human capital in the form of specific skills or talents. When she starts a firm, her human capital is essential to the firm. If there were no information or incentive problems then she could write a contract that would result in her supplying her human capital fully and the firm's value would be close to her private value. ${ }^{4}$ However, since human capital cannot be sold or, in many instances, efficiently contracted over, the actual value is substantially lower than her private value. The entrepreneur solves this problem by transforming her human capital into what we call "organization capital." The organization capital can be sold as part of the firm, so that the dynamic process of transforming human capital into organization capital means that the value of the firm increases over time. By

\footnotetext{
${ }^{4}$ See Wu (1989) for a background on why no one may be willing to hire entrepreneurs.
} 
this process the entrepreneur uses her specific human capital to accumulate general, tradable assets.

The process of using human capital to create organization capital is the focus of our analysis. We define organization capital to be information, specific to the firm, which allows the firm to transform technological know-how and factors of production into products and services it can sell in the market. The organization capital is thus embodied in the firm and has value.

The dynamic optimization problem faced by the entrepreneur is as follows. The entrepreneur's time weighted by her human capital is used directly in the production process to produce output and is also used to produce organization capital. Organization capital is an imperfect substitute for human capital in the production process. The entrepreneur must, therefore, decide how much time to devote to current production, how much to devote to building organization capital which earns a return in the future and how much leisure to consume. Given the leisure-work decision, the entrepreneur trades off creating more organization capital now, which means that the firm has substantial value sooner, against using that human capital for current production, which generates income in the current period. The solution to this dynamic optimization problem pins down the evolution of organization capital over time and the rate at which the value of the firm grows. As the firm evolves over time, the entrepreneur transforms her human capital, a specific, non-tradable asset, into a general asset that is tradable in the market.

We develop and solve a very simple model of the evolution of the firm which yields a number of results. First, we show that the entrepreneur devotes a lot of time in the initial stages to creating organization capital but decreases her time as the firm evolves. We show that the stock of organization capital increases at a decreasing rate. Finally, we show that the value of the firm (the value without 
the entrepreneur) increases over time, gets closer to entrepreneur's value, but is always below the entrepreneur's value (which includes the entrepreneur's efforts to increase organization capital.)

Our idea of organization capital as accumulated knowledge embodied in the firm, is similar to the type of capital considered by Marshall (1930). In related work, Rosen (1972) and, more recently, Atkeson and Kehoe (2005) develop models in which the firm produces organization capital and output as a bundle. In contrast, in our model there is a trade-off - the entrepreneur has to divide her time between production of output and creation of organization capital. In Prescott and Visscher (1980), the organization capital is embodied in the firm's workers. In such models, the difference between the value of the firm to the entrepreneur and others is likely to be small. In our model, the organization capital is embodied in the firm and hence, the difference between the value of the firm to the entrepreneur and to outsiders depends upon how important the entrepreneur is to the future of the firm.

\section{Model}

This is a model of one firm in a competitive market. An entrepreneur produces a product and sells it at a fixed price. For convenience we assume that this price is one. The entrepreneur hires labor, $l$, on the spot market at a wage $w$ and produces output using her human capital, $h$, and organization capital, $k$, along with the labor. The human capital is relatively specific on several dimensions; it may be specific to the product being produced, the location where it is produced, etc. The organization capital is an imperfect substitute for human capital in the production process.

Define $\tau_{t}^{p}$ to be the fraction of time the entrepreneur devotes to the production process in period $t$. Profit at time $t, x_{t}$, is then given by 


$$
x_{t}=F\left(k_{t}, \tau_{t}^{p} h, l_{t}\right)-w l_{t}
$$

where $F(\cdot)$ is increasing, strictly concave, and homogeneous of degree one. We have assumed that the entrepreneur's human capital $h$ and the market wage $w$ are constant over time.

The entrepreneur is also responsible for creating organization capital. The entrepreneur spends $\tau_{t}^{k}$ of her time producing organization capital. The stock of organization capital depends on how much time the entrepreneur devotes to creating it as well as how much is carried over from previous period. The following equation describes the evolution of the stock of organization capital:

$$
k_{t+1}=g\left(\tau_{t}^{k} h, k_{t}\right)
$$

Loosely speaking, $h$ represents the specific human capital that is essential to start the firm. In this case, $h$ may represent knowledge of how to convert a blueprint into a new commercial product. Without $h$ there is no product to produce. While knowledge of computer hardware, programming, networks etc. is a tradeable asset, knowledge of how to transform this into a marketable product is not. The entrepreneur not only performs this transformation, but also converts the specific human capital into a tradeable asset. She does so by making herself gradually inessential over time. In this process, she faces an intertemporal trade-off: her current consumption is enhanced by devoting more time to the production process but her future consumption will be enhanced if she devotes more time to creating organization capital.

The entrepreneur maximizes the sum of discounted utility over profits and leisure. We normalize the total amount of time available in a period to be one. Assume that the entrepreneur's utility function is logarithmic and that her subjective discount factor is $\beta$. Her problem is to choose $\tau^{p}, \tau^{k}$ and $l$ 
each period in order to maximize her discounted lifetime utility. Formally, the infinite horizon problem faced by the entrepreneur is

$$
\begin{aligned}
& \max \sum_{t=0}^{\infty} \beta^{t}\left\{\phi \ln \left(F\left(k_{t}, \tau_{t}^{p} h, l_{t}\right)-w l_{t}\right)+(1-\phi) \ln \left(1-\tau_{p}^{p}-\tau_{t}^{k}\right)\right\} \\
& \text { subject to, } \forall t \geq 0: \\
& k_{t+1}=g\left(k_{t}, \tau_{t}^{k} h\right), \\
& k_{0}>0 \text { given. }
\end{aligned}
$$

Notice that her problem does not explicitly depend on the time period once we know the beginning-of-period stock of organization capital. This helps us cast her infinite horizon optimization problem as the following dynamic program:

$$
\begin{aligned}
V(k)= & \max \phi \ln \left(F\left(k, \tau^{p} h, l\right)-w l\right)+(1-\phi) \ln \left(1-\tau^{p}-\tau^{k}\right)+\beta V\left(k^{\prime}\right) \\
& \text { subject to } k^{\prime}=g\left(k, \tau^{k} h\right),
\end{aligned}
$$

where $V(k)$ is the (endogenous) value of the entrepreneur's objective when she currently has $k$ units of organization capital, $\tau^{p}, \tau^{k}$ and $l$ are current choices of the entrepreneur's time for production, time for organization capital accumulation and labor, and $k^{\prime}$ is the next period's chosen level of organization capital.

It is easy to show that there exists a unique function $V(\cdot)$ that solves the above Bellman's functional equation (see Alvarez and Stokey ( 1998)). Furthermore, $V(\cdot)$ is increasing, concave, and differentiable. These properties of $V(\cdot)$ imply that the choice variables $\tau^{p}, \tau^{k}, l$, and $k^{\prime}$ are all stationary functions of $k$ i.e., while the values of $\tau, l$, and $k^{\prime}$ change over time, the function describing the values does not.

The first order conditions are 


$$
\begin{aligned}
\tau^{p}: \phi \frac{F_{2}\left(k, \tau^{p} h, l\right) h}{F\left(k, \tau^{p} h, l\right)-w l} & =(1-\phi) \frac{1}{1-\tau^{p}-\tau^{k}} \\
\tau^{k}:(1-\phi) \frac{1}{1-\tau^{p}-\tau^{k}} & =\beta V^{\prime}\left(k^{\prime}\right) g_{2}\left(k, \tau^{k} h\right) h \\
& l: F_{3}\left(k, \tau^{p} h, l\right)=w .
\end{aligned}
$$

The Envelope Theorem implies that

$$
V^{\prime}(k)=\phi \frac{F_{1}\left(k, \tau^{p} h, l\right)}{F\left(k, \tau^{p} h, l\right)-w l}
$$

Combining equations (2) and (4) gives us

$$
(1-\phi) \frac{F_{2}\left(k, \tau^{p} h, l\right)}{F\left(k, \tau^{p} h, l\right)-w l}=\beta \phi \frac{F_{1}\left(k^{\prime}, \tau^{p^{\prime}} h, l^{\prime}\right)}{F\left(k^{\prime}, \tau^{p^{\prime}} h, l^{\prime}\right)-w l^{\prime}} g_{2}\left(k, \tau^{k} h\right) .
$$

Thus, equations (1), (3) and (5) describe the economy.

\section{Value of organization capital}

Since we emphasize the role of the entrepreneur as one of transforming specific non-tradable human capital into tradable organization capital, it would be interesting to know the valuation of the enterprise with and without the entrepreneur. Our model suggests that the discounted sum of utilities is the value of the enterprise to the entrepreneur. The value to the entrepreneur with $k_{t}$ units of organization capital in period $t$ is

$$
\begin{aligned}
V\left(k_{t}\right)= & \max \sum_{s=t}^{\infty} \beta^{s-t}\left[\phi \ln \left(F\left(k_{s}, \tau_{s}^{p} h, l_{s}\right)-w l_{s}\right)+(1-\phi) \ln \left(1-\tau_{s}^{p}-\tau_{s}^{k}\right)\right] \\
& \text { subject to } k_{s+1}=g\left(k_{s}, \tau_{s}^{k} h\right) .
\end{aligned}
$$

We can also compute the discounted sum of utilities without the entrepreneur's time but with the organization capital; this we call the value of the firm without the entrepreneur or the value of the firm. To compute the value at any point in time, we set the level of organization capital equal to the entrepreneur's chosen level at the time and then calculate the discounted sum of utilities. Since, $h=0, k_{t+1}=g\left(k_{t}, 0\right)$ and $x_{t}=F\left(k_{t}, 0, l_{t}\right)-w l_{t}$. 
The value of a firm with $k$ units of organization capital but without the entrepreneur's human capital would be

$$
\begin{aligned}
\widehat{V}\left(k_{t}\right)= & \max \sum_{s=t}^{\infty} \beta^{s-t}\left[\phi \ln \left(F\left(k_{s}, 0, l_{s}\right)-w l_{s}\right)+(1-\phi) \ln (1)\right] \\
& \text { subject to } k_{s+1}=g\left(k_{s}, 0\right) .
\end{aligned}
$$

We next calibrate the model to see how it behaves and do some simple comparative static exercises.

\section{Calibration}

We adopt a particular functional form for the production function and law of motion of organization capital.

$$
\begin{aligned}
F\left(k, \tau^{p} h, l\right) & =\left[\mu\left(\tau^{p} h\right)^{\rho}+(1-\mu) k^{\rho}\right]^{\frac{\alpha}{\rho}} l^{1-\alpha} \\
k^{\prime} & =\left[\mu\left(\tau^{k} h\right)^{\rho}+(1-\mu)(k)^{\rho}\right]^{\frac{1}{\rho}}
\end{aligned}
$$

Given these functional forms, equations (1), (3) and (5) become

$$
\begin{aligned}
\phi \frac{\mu\left(\tau^{p} h\right)^{\rho}}{\tau^{p}\left[\mu\left(\tau^{p} h\right)^{\rho}+(1-\mu) k^{\rho}\right]}=(1-\phi) \frac{1}{1-\tau^{p}-\tau^{k}} \\
l=b(w)\left[\mu\left(\tau^{p} h\right)^{\rho}+(1-\mu) k^{\rho}\right]^{\frac{1}{\rho}} \\
\quad \frac{1-\phi}{\phi} \frac{1}{\mu\left(\tau^{p} h\right)^{\rho}+(1-\mu) k^{\rho}}\left(\frac{\tau^{p}}{\tau^{k}}\right)^{\rho-1} \\
=\beta \frac{1}{\mu\left(\tau^{k} h\right)^{\rho}+(1-\mu)(k)^{\rho}} \frac{(1-\mu)\left(k^{\prime}\right)^{\rho-1}}{\mu\left(\tau^{p^{\prime}} h\right)^{\rho}+(1-\mu) k^{\prime \rho}}
\end{aligned}
$$

We next use these equations to compute a numerical solution to the model.

We have a number of technology parameters:

$\mu$-ratio of investment in organization capital to the stock of organization capital 
$\rho$-substitutability of investment with existing organization capital

$\alpha$-profit to output ratio

$h$-human capital

$Z$-total factor productivity

$w$-wage rate

and preference parameters:

$\phi$-weight indicating preference over leisure

$\beta$-discount rate.

The calibration strategy is the following. We first fix the level parameters $h, Z$, and $w$. The levels of these are arbitrary so we set $h=3, Z=3$ and $w=1$. $\beta$ is set to a standard value, 0.96 which typically implies a real interest rate of $4 \%$. We set $\rho=0.95$. This means that investment in organization capital is a close substitute for existing organization capital. We use the "Survey of Private Enterprise" to compute the value of profit-output ratio, $\alpha=0.732$. Output is defined to be net profit + wage payments. We calculate the profitoutput ratio of manufacturing, wholesale, retail, and service industries from 1980 to 2005 in Japan. Using GDP share, we take the weighted average of these industries in each year and then take the average over the entire sample period.

Finally, we determine $\phi$ and $\mu$. We jointly calibrate these two parameters to match the steady state hours worked and steady state investment to capital ratio. We calculate the steady state hours worked as follows. Since we have normalized the time available to the entrepreneur as 1 , we take the average weekly hours worked in Japan during 1980-2005 and divide by 112 (16 hours each day times seven days). The fraction is $0.368 .{ }^{5}$ Our steady state investment is $\mu^{\frac{1}{\rho}} \tau^{k} h$. We calculate the capital stock with the perpetual

\footnotetext{
${ }^{5}$ Source: Monthly Labor Survey issued the Ministry of Labor.
} 
inventory method. ${ }^{6}$ We set the initial capital stock to be the same as that in Hayashi and Prescott (2002). This calcualtion yields the average investment to capital ratio in Japan from 1980 to 2005 to be 0.1332 . The reason we set organization capital investment to organization capital ratio as the same as the one with physical capital is because of the research by Corrado, Hulten and Sichel (2006). They found that intangible investment to tangible investment ratio in the United States during 1990s is 1.1. With these targets we find that $\phi=0.4264$ and $\mu=0.1473$.

The calculated parameters imply the following steady state values of the

$\begin{array}{lr}\text { variables: } & \\ K^{*} & 1.100 \\ L^{*} & 0.691 \\ \tau^{k *} & 0.367 \\ \tau^{p *} & 0.000 \\ \tau^{k *}+\tau^{p *} & 0.367 \\ V\left(K^{*}\right) & 0.214 \\ Y^{*} & 2.577 \\ X^{*} & 0.147 \\ X^{*} / K^{*} & 0.133 \\ \pi^{*} / Y^{*} & 0.732\end{array}$

\section{Benchmark Results}

Next, using the approximated value function and policy functions, we simulate the model for 25 years. The initial level of organization capital is 0.01 . Organization capital takes nineteen periods to reach $99 \%$ level of the steady state which is 1.1. (See Figure 1.)

For the first few periods, an entrepreneur devotes more than $50 \%$ of her time endowment for work (production + organization capital formation). As Figure 2 shows, she spends $58 \%$ of her time for work in the second pe-

\footnotetext{
${ }^{6}$ Investment data source is "Annual Report on National Accounts" issued by Department of National Accounts, ESRI
} 


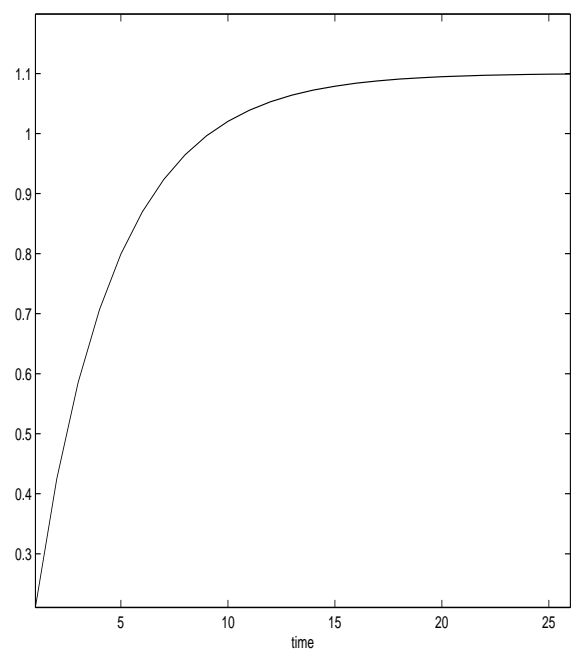

Fig. 1. Evolution of Organization Capital

riod, which is quite similar to the one reported in the "Survey of New Entrepreneurs' Activity" in 2002 issued by National Life Finance Corporation (an entrepreneur uses $55 \%$ of her time for work). On the other hand, growth in

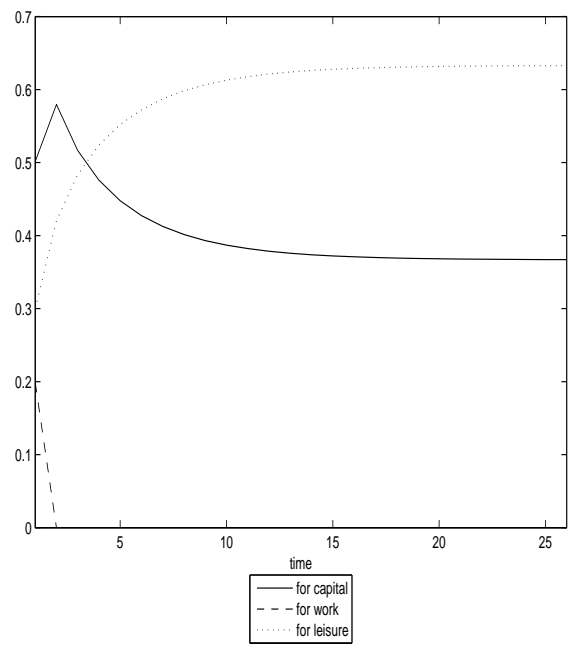

Fig. 2. Evolution of Time Allocation by the Entrepreneur

labor (Figure 3) in the first four periods is much larger than the one reported 
in the same survey (Model: 553\%, Data:71\%). As shown in Figure 4, average

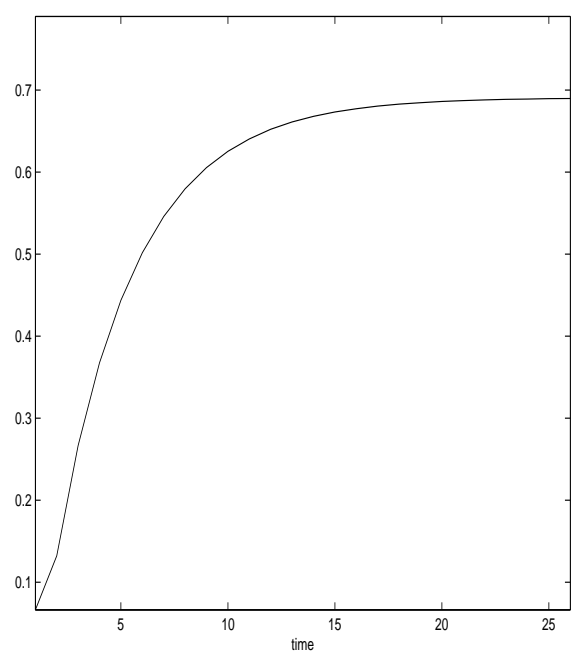

Fig. 3. Evolution of Labor Hired by the Entrepreneur

growth of profit in 25 years is $9.8 \%$, which is also larger than the data $(2.8 \%$ from 1980 to 2005) reported in the National Accounts. ${ }^{7}$

In the benchmark case, the entrepreneur stops working at production activities after two periods. Furthermore, time for capital accumulation is concave. When the level of organization capital is low, the entrepreneur needs to work. However, once she reaches a certain level of organization capital, she stops working on production and also begins to reduce the time spent on organization capital formation. Figure 5 shows that the value to the entrepreneur as well as the value of the firm without the entrepreneur increases over time. The gap between the values narrows, but it does not seem to converge to zero.

\footnotetext{
7 Source: Profit of Private unincorporated enterprizes in "Annual Report on National Accounts" issued by Department of National Accounts, ESRI.
} 


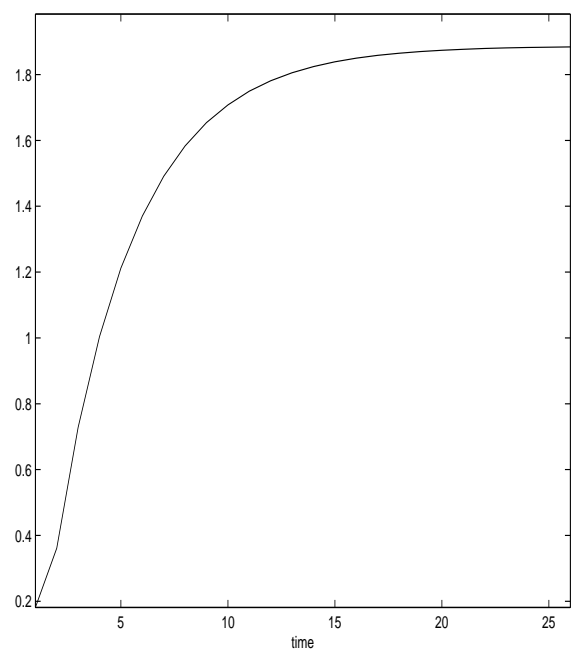

Fig. 4. Evolution of Profit

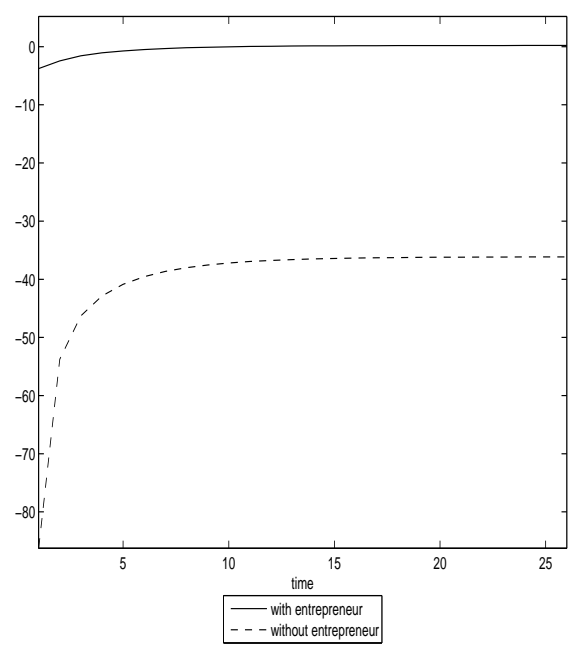

Fig. 5. Evolution of the Values of the Firm

\section{Comparative Statics}

We do some simple comparative static exercises to examine the effect of changes in $\rho, \mu \phi$ and $h$. We first look at lower values of $\rho, \rho=0.90$ and $\rho=0.85$. Decreases in $\rho$ decreases the steady state level of investment, employment and value of the firm. In the simulation, decreases in $\rho$ increases 
growth of profit. Second, we look at what happens if investment in organization capital is a larger percentage of the stock of organization capital ( $\mu=0.3$ and $\mu=0.5) . \mu$ has a strong impact on the steady state level of organization capital, but the change is not monotone in $\mu$. Increasing $\mu$ from the benchmark value to 0.3 raises the steady state organization capital. But, when $\mu$ increases from 0.3 to 0.5 , the steady state level of organization capital decreases dramatically. Third, we consider a lower and a higher value of $\phi(\phi=0.3$ and $\phi=0.55)$. When the entrepreneur cares more about income relative to leisure she works more. Both steady state hours devoted to organization capital and hours worked towards production increase as $\phi$ goes up. Thus the firm grows faster as $\phi$ rises. Finally, we analyze the effect of human capital ( $h=2$ and $h=4)$. The steady state level of organization capital and the number of employees increase as the level of human capital increases. On the other hand, change in human capital does not affect the steady state time allocation. The impact of the level of human capital on the marginal benefits of time for production and investment are exactly the same in the steady state so that the steady state time allocation is independent of $h$. Because of our production function, labor demand is increasing function of $h \tau^{p}$. Since $\tau^{p}$ does not change in the steady state, increasing $h$ increases the number of employees. Also, the steady state level of organization capital is increasing in $h \tau^{k}$. Therefore, it increases as $h$ increases.

\section{Concluding Comments}

In developing a theory of start-up firms or entrepreneurship we focus on the role of organization capital. The entrepreneur is able to transform her human capital into a marketable asset, which we call organization capital, by building an effective business organization, thereby making herself inessential over 
time. This organization capital can be used by the entrepreneur to generate future streams of profits and create value.

Our view is that organization capital plays an important role in determining the value of a firm. When firms are sold the price the firm sells for reflects future profitability. But what is it that the buyer is actually buying? Our view is that besides the physical assets when you buy a business you are in large part purchasing the organization capital.

Our model implies that the firm increases organization capital at a decreasing rate. Labor demand by the firm (and profits) also increases at a decreasing rate. This means that the value of a firm increases at a decreasing rate.

We think this framework will be useful in analyzing the behavior of multinational firms. For example, consider a multinational firm that wants to take advantage of cheap inputs available in another country. It could choose to operate a plant in that country, enter into a joint venture with a local firm or contract out to a local firm. Our model suggests that their choice of mode of entry into this market will be affected by the way organization capital is created by the multinational firm.

There are many important issues that we have not dealt with at this point, such as the extent to which organization capital is embodied in people, whether organization capital can be purchased and transferred to other uses and to what extent organization capital is a public good. We leave these issues for future research. 
Entrepreneurship, Organization Capital and the Evolution of the Firm

\section{References}

[1] Alvarez, F. and N. L. Stokey (1998) Dynamic programming with homogeneous functions. Journal of Economic Theory 82:167-189

[2] Atkeson, A. and P. J. Kehoe (2005) Modeling and measuring organization capital. Journal of Political Economy 113(5):1026-1053

[3] Baumol, W. J. (1986) Productivity growth, convergence, and welfare: What the long-Run data show. American Economic Review 76(5):10721086

[4] Baumol, W. J. (1990) Entrepreneurship: Productive, unproductive, and destructive. Journal of Political Economy 98(5):893-921

[5] Corrado, Carol A., Charles R. Hulten and Daniel E. Sichel (2006) Intangible capital and economic growth. NBER Working Paper, No. 11948.

[6] Harada, Nobuyuki (2003) Kigyouka no roudoujikan. JCER Discussion Paper, No. 85 in Japanese

[7] Hayashi, Fumio and Edward C. Prescott (2002) The 1990s in Japan: A lost decade. Review of Economic Dynamics 5(1):206-235

[8] Holmes, T. J. and J. A. Schmitz (1990) A theory of entrepreneurship and its application to the study of business transfers. The Journal of Political Economy 98(2):265-294

[9] Kihlstrom, R. and J. J. Laffont (1979) A general equilibrium theory of the firm based on risk aversion. Journal of Political Economy 87(4):719748

[10] Knight, F. H. (1971) Risk, uncertainty and profit. Chicago: University of Chicago Press.

[11] Marshall, A. (1930) Principles of Economics: An Introductory Volume. 8th edition, London: Macmillan 
[12] Prescott, E. C. and M. Visscher (1980) Organization capital. Journal of Political Economy 88(3):446-461

[13] Schumpeter, J. A. (1949) The theory of economic development. Cambridge: Harvard University Press

[14] Wu, S. Y. (1989) Production, entrepreneurship and profit. New York: Basil Blackwell 
Entrepreneurship, Organization Capital and the Evolution of the Firm

\section{Appendix: Data Sources}

\section{Harada (2003)}

This paper, written in Japanese, analyzes working hours of entrepreneurs who had set up their business three to seven years before 2002 (so they started their business between 1995 and 1999). He collected data by questionnaires. The sample size is 755 . He asked the survey participants,

Could please answer the number of weekly hours that you think you use for your business? For your information, one week is $24 h \times 7$ days $=168 h^{8}$.

According to his survey, the average number of hours worked in a week is 66. About $87 \%$ of the entrepreneurs in the sample work more than 41 hours a week, $63 \%$ work more than 61 hours a week. This is about 18 hours longer than the average weekly working hours of full-time employees. ${ }^{9}$

\section{National Life Finance Cooperation}

Hours worked "Survey of New Entrepreneurs' Activities" in 2002 reports the average daily working hours of an entrepreneur who started his business between April and September in 2000. The interviews were done in August 2002. The average business length in the sample is 14.8 months. Thus, the sample is restricted to fairly new entrepreneurs.

The report shows that a new entrepreneur works 10.4 hours a day on average. About $15 \%$ of the entrepreneurs in the sample work more than 13 hours a day. Entrepreneurs working less than 6 hours a day are only $4.2 \%$ of the sample. Furthermore, the number of holidays taken in a month is 4.3 on

\footnotetext{
${ }^{8}$ English translation from Japanese.

9 See "Labor Force Survey" issued by the Ministry of International Affairs and communications.
} 
average. This means that the new entrepreneurs work 6 days a week. Using these facts, the average weekly hours worked would be about 62.4 hours which is pretty close to the results in Harada (2003). ${ }^{10}$ Therefore, we could say that a typical entrepreneur in Japan works much longer than other types of workers when her business is in early stage.

There is another interesting feature in the statistics of entrepreneurs' holidays. About 11 percent of the sample do not take holidays at all. The share of an entrepreneur who takes less than three days in a month is $23.5 \%$. About a quarter of a new entrepreneurs work 7 days a week at some points during a month. This tells us that entrepreneurs' time endowment could be very different from the usual employees' one.

Employees "Panel Survey of New Entrepreneurs' Activities" in 2005 documents the number of workers in the firms from 2001 to 2004. They interview the companies starting in 2001. The average number of workers (including entrepreneurs themselves) increases from 4.1 to $6.3 .{ }^{11}$ These numbers tell us that the employment would increase about $53 \%$ in four years.

There is another source of information on the number of workers employed by entrepreneurs. "Survey of New Entrepreneurs' Activities" in 2003 keeps track of the number of workers at the time the entrepreneur started her business, and the number when the NLFC surveyed, from 1991 to 2003. The average lag is 15 months. Hence, the NLFC has data about how many additional workers an entrepreneur hires 15 months after she started up her business. The average growth rate of workers in the first 15 months between 1991 and 2003 is $28 \%$.

\footnotetext{
${ }^{10}$ However, the samples in Harada (2003) started their business 1 to 7 years earlier.

11 The sample number is 849 .
} 


\section{CESifo Working Paper Series}

for full list see www.cesifo-group.org/wp

(address: Poschingerstr. 5, 81679 Munich, Germany, office@cesifo.de)

2180 Emilia Del Bono, Andrea Weber and Rudolf Winter-Ebmer, Clash of Career and Family: Fertility Decisions after Job Displacement, January 2008

2181 Harald Badinger and Peter Egger, Intra- and Inter-Industry Productivity Spillovers in OECD Manufacturing: A Spatial Econometric Perspective, January 2008

2182 María del Carmen Boado-Penas, Salvador Valdés-Prieto and Carlos Vidal-Meliá, the Actuarial Balance Sheet for Pay-As-You-Go Finance: Solvency Indicators for Spain and Sweden, January 2008

2183 Assar Lindbeck, Economic-Social Interaction in China, January 2008

2184 Pierre Dubois, Bruno Jullien and Thierry Magnac, Formal and Informal Risk Sharing in LDCs: Theory and Empirical Evidence, January 2008

2185 Roel M. W. J. Beetsma, Ward E. Romp and Siert J. Vos, Intergenerational Risk Sharing, Pensions and Endogenous Labor Supply in General Equilibrium, January 2008

2186 Lans Bovenberg and Coen Teulings, Rhineland Exit?, January 2008

2187 Wolfgang Leininger and Axel Ockenfels, The Penalty-Duel and Institutional Design: Is there a Neeskens-Effect?, January 2008

2188 Sándor Csengődi and Dieter M. Urban, Foreign Takeovers and Wage Dispersion in Hungary, January 2008

2189 Joerg Baten and Andreas Böhm, Trends of Children's Height and Parental Unemployment: A Large-Scale Anthropometric Study on Eastern Germany, 1994 2006, January 2008

2190 Chris van Klaveren, Bernard van Praag and Henriette Maassen van den Brink, A Public Good Version of the Collective Household Model: An Empirical Approach with an Application to British Household Data, January 2008

2191 Harry Garretsen and Jolanda Peeters, FDI and the Relevance of Spatial Linkages: Do third Country Effects Matter for Dutch FDI?, January 2008

2192 Jan Bouckaert, Hans Degryse and Theon van Dijk, Price Discrimination Bans on Dominant Firms, January 2008

2193 M. Hashem Pesaran, L. Vanessa Smith and Takashi Yamagata, Panel Unit Root Tests in the Presence of a Multifactor Error Structure, January 2008 
2194 Tomer Blumkin, Bradley J. Ruffle and Yosef Ganun, Are Income and Consumption Taxes ever really Equivalent? Evidence from a Real-Effort Experiment with Real Goods, January 2008

2195 Mika Widgrén, The Impact of Council's Internal Decision-Making Rules on the Future EU, January 2008

2196 Antonis Adam, Margarita Katsimi and Thomas Moutos, Inequality and the Import Demand Function, January 2008

2197 Helmut Seitz, Democratic Participation and the Size of Regions: An Empirical Study Using Data on German Counties, January 2008

2198 Theresa Fahrenberger and Hans Gersbach, Minority Voting and Long-term Decisions, January 2008

2199 Chiara Dalle Nogare and Roberto Ricciuti, Term Limits: Do they really Affect Fiscal Policy Choices?, January 2008

2200 Andreas Bühn and Friedrich Schneider, MIMIC Models, Cointegration and Error Correction: An Application to the French Shadow Economy, January 2008

2201 Seppo Kari, Hanna Karikallio and Jukka Pirttilä, Anticipating Tax Change: Evidence from the Finnish Corporate Income Tax Reform of 2005, January 2008

2202 Walter Krämer and André Güttler, On Comparing the Accuracy of Default Predictions in the Rating Industry, January 2008

2203 Syed M. Ahsan and Panagiotis Tsigaris, The Efficiency Loss of Capital Income Taxation under Imperfect Loss Offset Provisions, January 2008

2204 P. Mohnen, F. C. Palm, S. Schim van der Loeff and A. Tiwari, Financial Constraints and other Obstacles: Are they a Threat to Innovation Activity?, January 2008

2205 Sascha O. Becker and Mathias Hoffmann, Equity Fund Ownership and the CrossRegional Diversification of Household Risk, January 2008

2206 Pedro R. D. Bom and Jenny E. Ligthart, How Productive is Public Capital? A MetaAnalysis, January 2008

2207 Martin Werding, Ageing and Productivity Growth: Are there Macro-level Cohort Effects of Human Capital?, January 2008

2208 Frederick van der Ploeg and Steven Poelhekke, Globalization and the Rise of MegaCities in the Developing World, February 2008

2209 Sara Biancini, Regulating National Firms in a Common Market, February 2008

2210 Jin Cao and Gerhard Illing, Liquidity Shortages and Monetary Policy, February 2008 
2211 Mathias Kifmann, The Design of Pension Pay Out Options when the Health Status during Retirement is Uncertain, February 2008

2212 Laszlo Goerke, Tax Overpayments, Tax Evasion, and Book-Tax Differences, February 2008

2213 Jun-ichi Itaya and Heinrich W. Ursprung, Price and Death, February 2008

2214 Valentina Bosetti, Carlo Carraro and Emanuele Massetti, Banking Permits: Economic Efficiency and Distributional Effects, February 2008

2215 Assar Lindbeck, Mårten Palme and Mats Persson, Social Interaction and Sickness Absence, February 2008

2216 Gary E. Bolton and Axel Ockenfels, The Limits of Trust in Economic Transactions Investigations of Perfect Reputation Systems, February 2008

2217 Hartmut Egger and Peter Egger, The Trade and Welfare Effects of Mergers in Space, February 2008

2218 Dorothee Crayen and Joerg Baten, Global Trends in Numeracy 1820-1949 and its Implications for Long-Run Growth, February 2008

2219 Stephane Dees, M. Hashem Pesaran, L. Vanessa Smith and Ron P. Smith, Identification of New Keynesian Phillips Curves from a Global Perspective, February 2008

2220 Jerome L. Stein, A Tale of Two Debt Crises: A Stochastic Optimal Control Analysis, February 2008

2221 Michael Melvin, Lukas Menkhoff and Maik Schmeling, Automating Exchange Rate Target Zones: Intervention via an Electronic Limit Order Book, February 2008

2222 Raymond Riezman and Ping Wang, Preference Bias and Outsourcing to Market: A Steady-State Analysis, February 2008

2223 Lars-Erik Borge and Jørn Rattsø, Young and Old Competing for Public Welfare Services, February 2008

2224 Jose Apesteguia, Steffen Huck, Jörg Oechssler and Simon Weidenholzer, Imitation and the Evolution of Walrasian Behavior: Theoretically Fragile but Behaviorally Robust, February 2008

2225 Walter Krämer, Long Memory with Markov-Switching GARCH, February 2008

2226 António Afonso and Christophe Rault, What do we really Know about Fiscal Sustainability in the EU? A Panel Data Diagnostic, February 2008

2227 Sergey M. Kadochnikov and Igor M. Drapkin, Market Structure, Technological Gap and Vertical Linkage Effects from Foreign Direct Investment, February 2008 
2228 Guglielmo Maria Caporale, Davide Ciferri and Alessandro Girardi, Fiscal Shocks and Real Exchange Rate Dynamics: Some Evidence for Latin America, February 2008

2229 Scott Alan Carson, Geography and Insolation in $19^{\text {th }}$ Century US African-American and White Statures, February 2008

2230 Wolfgang Buchholz and Jan Schumacher, Discounting and Welfare Analysis Over Time: Choosing the $\eta$, February 2008

2231 M. Hashem Pesaran, Christoph Schleicher and Paolo Zaffaroni, Model Averaging in Risk Management with an Application to Futures Markets, February 2008

2232 Wilhelm Kohler, Offshoring: Why Do Stories Differ?, February 2008

2233 Stefan Bach, Giacomo Corneo and Viktor Steiner, Effective Taxation of Top Incomes in Germany, 1992-2002, February 2008

2234 Robert S. Chirinko, $\sigma:$ The Long And Short Of It, February 2008

2235 Volker Grossmann and Holger Strulik, Should Continued Family Firms Face Lower Taxes than other Estates?, February 2008

2236 Guido Tabellini, The Scope of Cooperation: Values and Incentives, February 2008

2237 Heinrich W. Ursprung and Christian Wiermann, Reputation, Price, and Death: An Empirical Analysis of Art Price Formation, March 2008

2238 Hans Fehr and Christian Habermann, Private Retirement Savings in Germany: The Structure of Tax Incentives and Annuitization, March 2008

2239 Joseph Francois and Ian Wooton, Market Structure and Market Access, March 2008

2240 Hiroyuki Kasahara and Beverly Lapham, Productivity and the Decision to Import and Export: Theory and Evidence, March 2008

2241 Gary E. Bolton and Axel Ockenfels, Does Laboratory Trading Mirror Behavior in Real World Markets? Fair Bargaining and Competitive Bidding on EBay, March 2008

2242 Atsushi Oshima, B. Ravikumar and Raymond Riezman, Entrepreneurship, Organization Capital and the Evolution of the Firm, March 2008 